Japanese Journal of Herpetology 11(1): 5-10. 1985.

\title{
Study of Thumb Pad Regions Developed by the Administration of Testosterone in a Young Female of Rana nigromaculata with a Supernumerary Forelimb
}

\author{
Hisaaki IWASAWA* and Toshikatsu TAKASU*
}

\begin{abstract}
A young female Rana nigromaculata with a supernumerary forelimb was collected in a paddy field. The administration of testosterone to this frog induced the development of the thumb pads on the normal forelimbs as well as on the supernumerary limb. The skeletal structure of the manual region and histological structure of the thumb pads are described. Studies of this kind seem to be effective in solving the mechanism inducing pad development on a specific part of the fingers.
\end{abstract}

The pads found on the thumbs of adult male frogs are one of the androgendependent sexual characters (Dodd, 1960; Lofts, 1974). But the mechanism inducing pad development on a definite part of the fingers is still unknown. By chance we obtained a young female frog which had a supernumerary forelimb. We administered testosterone to this frog and studied it to find out whether or not a thumb padlike structure develops on the digits of a supernumerary limb having an abnormal structure.

\section{MATERIAL AND METHODS}

A young Rana nigromaculata with a supernumerary limb on the left side of the throat was found at the end of June at Kanazuka, Niigata Prefecture. This frog was a female about one year old, and its body length was $45 \mathrm{~mm}$ and weight was $9.3 \mathrm{~g}$. The frog was kept at room temperature $\left(25 \pm 2{ }^{\circ} \mathrm{C}\right)$ and fed on liver. An aqueous suspension of $0.3 \mathrm{mg}$ of testosterone crystals was injected subcutaneously every 3 days. After 10 injections, the skeletal system of this frog was observed by soft X-ray (SOFRON, Nouken Co., Ltd., Tokyo), after which the normal and supernumerary forelimbs were fixed with Bouin's solution. The left and right thumbs of the normal forelimbs and each digit of the supernumerary limb were cut off, embedded in paraffin, serially cross-sectioned at $8 \mu \mathrm{m}$, and stained with Mayer's hematoxylin and eosin. For histological measurement, the thumb pads developed

* Biological Institute, Faculty of Science, Niigata University, Niigata 950-21, Japan. 950-21 新潟市五十嵐, 新潟大学理学部生物学教室 
on the left and right normal forelimbs were divided into 3 levels: distal, middle and proximal from the digital tips. The height and number of papillae, the height of the mucous glands, and the epidermal thickness exclusive of papillae were measured at 20 points in each level. Because the thumb pad on the supernumerary limb was too small to measure in the same way, 20 points were chosen from all over the pad. The results of the measurements were tested statistically for significance by Student's $t$-test.

\section{RESULTS}

1. Structure of the digits of the supernumerary limb

The supernumerary limb had four digits, and these were less than half the length of the digits of the normal forelimbs (Figs. 1 and 2). Five metacarpi were observed and the metacarpus of digit I was very small. Both digits II and III had two phalanges and a similar structure to the normal forelimbs. Digits IV and $V$ had one phalange. These were covered together by the skin at the middle level of the digits, so that digital separation was incomplete. The whole skeletal structure of this limb has been described elsewhere (Takasu, 1982).

2. Thumb pad development induced by testosterone administration

The development of papillae and mucous glands was observed on digit II (socalled thumb) of the normal and supernumerary forelimbs (Fig. 3).

Normal forelimbs: The thumb pads were observed on the epidermis covering the metacarpal region (Fig. 2A). The width of the pad differed at different levels, but

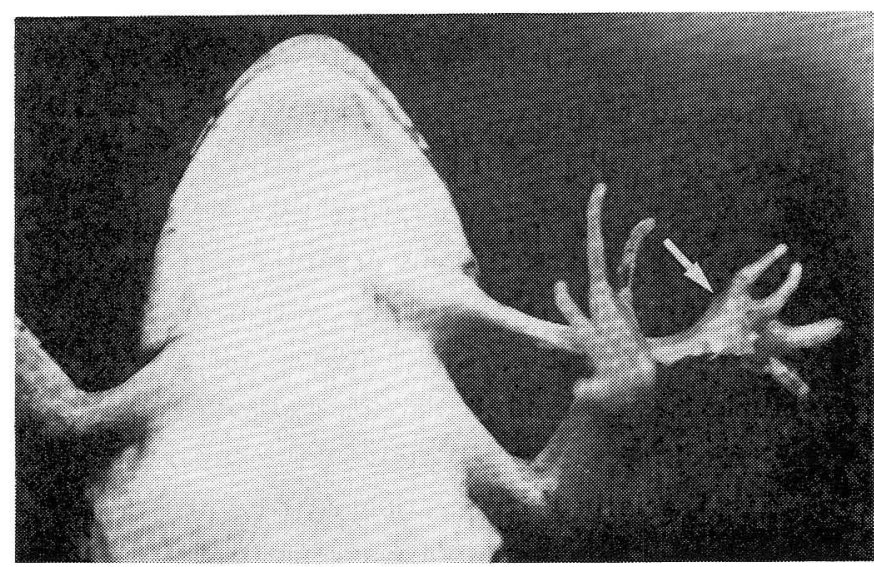

Fig. 1. Young female Rana nigromaculata with a supernumerary limb on the left side of the throat (ventral view). Arrow $=$ thumb pad. 

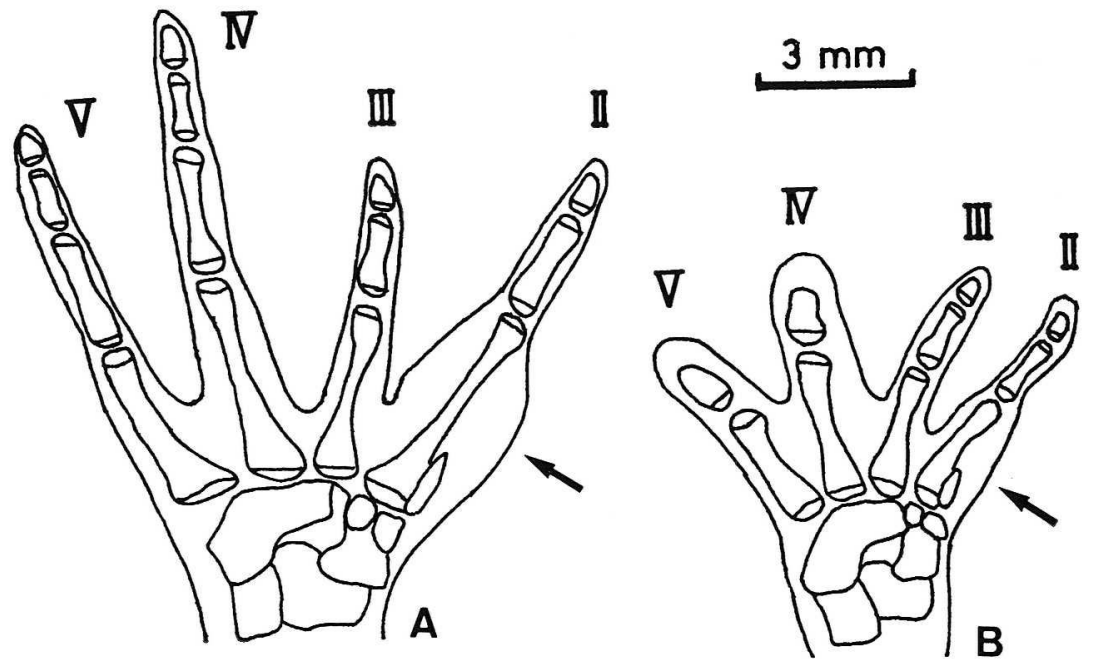

Fig. 2. Dorsal view of manual skeleton. A) Left forelimb. B) Supernumerary limb. Arrow $=$ thumb pad.

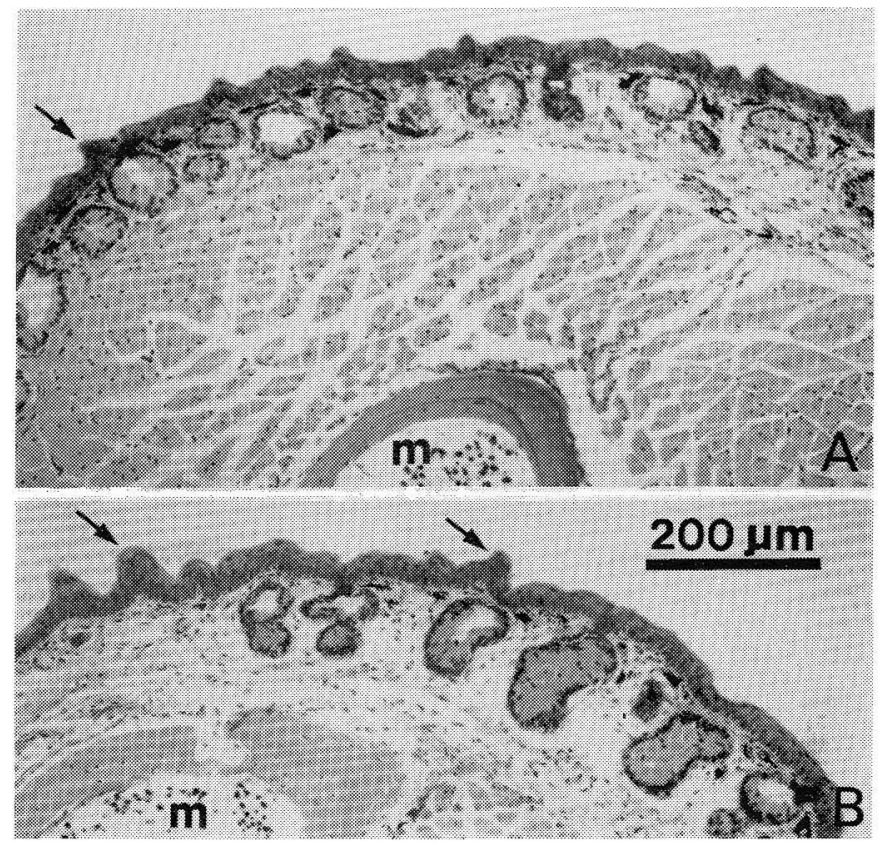

Fig. 3. Cross sections at the middle level of the thumb pads. A) Left forelimb. B) Supernumerary limb. Arrow= papilla, $m=$ metacarpus. 
Table 1. Histological measurement of thumb pads developed in a young female Rana nigromaculata treated with testosterone.

\begin{tabular}{lcccc}
\hline & $\begin{array}{c}\text { Epidermal } \\
\text { thickness* }\end{array}$ & $\begin{array}{c}\text { Height of papillae } \\
\text { including } \\
\text { epidermal thickness* }\end{array}$ & $\begin{array}{c}\text { Papillar } \\
\text { density** }\end{array}$ & $\begin{array}{c}\text { Height of } \\
\text { mucous gland* }\end{array}$ \\
\hline $\begin{array}{l}\text { Left forelimb } \\
\text { proximal }\end{array}$ & $27.3 \pm 4.8$ & $44.6 \pm 4.3$ & 1.0 & $84.2 \pm 17.2$ \\
middle & $24.0 \pm 3.2^{\mathrm{a}^{\prime}}$ & $42.7 \pm 6.5$ & 1.8 & $89.9 \pm 9.7$ \\
distal & $24.4 \pm 4.1$ & $43.8 \pm 4.4$ & 2.2 & $88.6 \pm 10.2$ \\
average & $25.2 \pm 4.3$ & $43.6 \pm 5.1^{\mathrm{b}^{\prime}}$ & 1.7 & $87.6 \pm 12.9^{\mathrm{c}^{\prime}}$ \\
\hline Right forelimb & & & & $88.0 \pm 16.0$ \\
proximal & $27.0 \pm 4.1$ & $42.8 \pm 3.8$ & 1.1 & $87.9 \pm 8.1$ \\
middle & $25.6 \pm 2.4$ & $48.9 \pm 3.8$ & 2.0 & $81.7 \pm 9.3$ \\
distal & $25.0 \pm 2.0$ & $47.9 \pm 6.8$ & 1.8 & 1.6 \\
average & $25.8 \pm 3.1$ & $46.5 \pm 5.4$ & $1.6 \pm 12.2^{\mathrm{c}^{\prime}}$ \\
\hline Supernumerary & & & 1.5 & $106.7 \pm 13.5^{\mathrm{c}}$ \\
limb & $26.1 \pm 3.1^{\mathrm{a}}$ & $48.3 \pm 7.1^{\mathrm{b}}$ & & \\
\hline
\end{tabular}

* Mean \pm std. dev. $(\mu \mathrm{m})$.

** Number of papillae per $1 \mathrm{~mm}$ width at $8 \mu \mathrm{m}$ cross section. a $>\mathrm{a}^{\prime}(P<.05)$, $\mathrm{b}>\mathrm{b}^{\prime}(P<.002), \mathrm{c}>\mathrm{c}^{\prime}(P<.01)$.

was about two fifths of the contour of the digit. Papillar density, that is, the number of papillae per $1 \mathrm{~mm}$ width of the cross section is shown in Table 1 . The papillar density in the proximal part was lower than in the other parts. As regards the epidermal thickness and the height of the mucous glands, no significance was, as a whole, recognized between the left and right forelimbs, although the papillae including the epidermis in the right limb were higher than in the left $\operatorname{limb}(P<$ 0.005), and the region where the mucous glands developed well wasnot always the region where papillae developed well.

Supernumerary limb: Development of the mucous glands and papillae was observed at the region covering the metacarpus of digit II (Fig. 2B). The digit was short and small, so the development of the pad was spatially limited. But the reaction of the skin of this region to testosterone was about equal to or even stronger than that of the thumbs of the normal forelimbs. That is, the epidemis of the pad of the supernumerary limb was slightly thicker than the epidermis at the middle level of the pad of the left limb $(P<0.05)$. The papillae developed on the pad of the supernumerary limb were significantly higher in average than those on the pad of the left limb $(P<0.002)$, but the difference from the papillae on the pad of the right limb was not significant. Concerning the density of the papillae, 
however, the development of the papillae seemed to be slightly superior in the supernumerary limb than in the left and right limbs. The mucous glands were well developed compared with those of the normal forelimbs $(P<0.01)$. The papillae developed well on the ventral surface of the digit, whereas the mucous glands developed rather well in the lateral region of the digit. In other words, as pointed out for the pads developed on the normal forelimbs, the region where papillae developed well was not necessarily the one where the mucous glands developed well.

\section{DISCUSSION}

The administration of testosterone induces the development of the thumb pad in young male and female frogs of this species (Iwasawa and Kobayashi, 1974). In the present study, the thumb pads were developed not only on the normal forelimbs but also on the supernumerary limb, which has a different anatomical structure from the normal forelimbs, following the administration of testosterone. As far as we are aware, the present paper is the first one dealing with this subject. Although the development of these thumb pads was poor as compared with that in the matured males of this species (Iwasawa and Asai, 1959), all the structures seen in the thumb pads of the adult males were definitely recognized in the testosterone-induced pads. It seems, therefore, that if the duration of the treatment is prolonged, the thumb pads of the frog may develop more with the advance of the experimental period (Iwasawa and Kobayashi, 1974). The degree of histological differentiation of the pad developed on the supernumerary limb was almost equal to or even stronger than that of the pads developed on the normal forelimbs. D'Istria et al. $(1975,1982)$ showed that androgen receptors are present generally in the epidermis of anurans. But the mechanism whereby the androgen receptors concentrate on a specific region of the forelimb is still unknown.

In adult males of Rana fusca, thumb pads autotransplanted onto the body surface of other regions showed normal histological changes according to the reproductive cycle of the species (Harms, 1912). In adult males of Bufo vulgaris, on the other hand, skin autotransplanted onto the basal region of digit II did not develop into the thumb pad (Ponse, 1926). So it seems that the acquisition of a peculiar responsiveness of the skin to androgen, thumb pad-forming ability, occurs during later stages of manual differentiation.

It seems that accumulated data on the relationship between the anatomical structure of the manual region and the development of the thumb pad enable us to estimate the factors determining the field of the thumb pad. Since regeneration of the forelimbs of anurans does not occur after they are cut off (Kurabuchi and 
Inoue, 1982), it is difficult to examine the development of the pad on regenerated digits. It seems, therefore, that the supernumerary limb is good material to use in studying this problem.

\section{LITERATURE CITED}

D'Istria, M., G. Delrio and G. Chieffi. 1975. Receptors for sex hormones in the skin of the Amphibia. Gen. Comp. Endocrinol., $26: 281-283$.

D'Istria, M., A. Picilli, C. Basile, G. Delrio and G. Chieffi. 1982. Morphological and biochemical variations in the skin of Rana esculenta during the annual cycle. Gen. Comp. Endocrinol., 48:20-24.

Dodd, J.M. 1960. Gonadal and gonadotrophic hormones in lower vertebrates. In: A. S. Parkes (ed.), Marshall's physiology of reproduction, vol. 1, part 2, Longmans, London, p. 417-582.

Harms, W. 1912. Beeinflussung der Daumenballen des Kastraten durch Transplantation auf normaler Rana fusca (Rös.). Zool. Anz., 39 : 145-151.

Iwasawa, H. and O. Asai. 1959. Histological observations on the seasonal change of the testis and the thumb pad in the frog, Rana nigromaculata. J. Fac. Sci., Niigata Univ., Ser. II, 2:213-219.

Iwasawa, H. and M. Kobayashi. 1974. Effects of testosterone and estradiol on the development of sexual characters in young Rana nigromaculata. Biol. Reprod., $11: 398-405$.

Kurabuchi, S. and S. Inoue. 1982. Limb regenerative capacity of four species of Japanese frogs of the families Hylidae and Ranidae. J. Morph., 173 : 129-135.

Lofts, B. 1974. Reproduction. In: B. Lofts (ed.), Physiology of the Amphibia, vol. II, Academic Press, New York, p. 107-218.

Ponse, K. 1926. Territoires cellulaires et caracteres sexuels seccndaires. Ccmpt. rend. scc. biol., 95: 950951.

Takasu, T. 1982. A pond frog (Rana nigromaculata) with a supernumerary limb on the left side of the throat. Nippon Herpetol. J., $23: 23-25$. (in Japanese)

要 旨

過剩前肢をもつ幼若雌トノサマガェルに拈けるテストステロン投与による

指たこ発生部位の検討岩沢 久彰・高須 俊克

左前肢の頭方に過剩肢をもつトノサマガェルの幼若雌を野外で採集した。この個体にテスト ステロンを $0.3 \mathrm{mg}$ ずつ 3 日ごとに 10 回投与したところ, 左右の正常肢の最内側指の内側基部 と過剩肢のそれに相当する部分に指たこが発生した。この個体の正常肢と過剩肢の掌・指部の 外形と骨格扔よび指たこの組織構造を記載した。指たこは成体雄カエルの指の特定の部分に発 生する第二次性徵であるが, 特定の部分にのみ発生する機構は不明である。この問題の解明に は, 異った構造の過剩前肢をもつ個体にテストステロンを投与し, 指たこの発生と手の構造と の関連性を検討することが有効と考えられる。 